\title{
The effect of the salinity, light regime and food source on carbon and nitrogen uptake in a benthic foraminifer
}

\author{
Michael Lintner ${ }^{1}$, Bianca Lintner ${ }^{1}$, Wolfgang Wanek ${ }^{2}$, Nina Keul ${ }^{3}$, and Petra Heinz ${ }^{1}$ \\ ${ }^{1}$ Department of Palaeontology, University of Vienna, Vienna, Austria \\ ${ }^{2}$ Division of Terrestrial Ecosystem Research, Department of Microbiology and Ecosystem Science, \\ University of Vienna, Vienna, Austria \\ ${ }^{3}$ Institute of Geosciences, Christian-Albrechts-Universität zu Kiel, Kiel, Germany
}

Correspondence: Michael Lintner (michael.lintner@univie.ac.at)

Received: 6 August 2020 - Discussion started: 25 August 2020

Revised: 4 January 2021 - Accepted: 19 January 2021 - Published: 23 February 2021

\begin{abstract}
Foraminifera are unicellular organisms that play an important role in marine organic matter cycles. Some species are able to isolate chloroplasts from their algal food source and incorporate them as kleptoplasts into their own metabolic pathways, a phenomenon known as kleptoplastidy. One species showing this ability is Elphidium excavatum, a common foraminifer in the Kiel Fjord, Germany. The Kiel Fjord is fed by several rivers and thus forms a habitat with strongly fluctuating salinity. Here, we tested the effects of the food source, salinity and light regime on the food uptake (via ${ }^{15} \mathrm{~N}$ and ${ }^{13} \mathrm{C}$ algal uptake) in this kleptoplast-bearing foraminifer. In our study E. excavatum was cultured in the lab at three salinity levels (15, 20 and 25) and uptake of $\mathrm{C}$ and $\mathrm{N}$ from the food source Dunaliella tertiolecta (Chlorophyceae) and Leyanella arenaria (Bacillariophyceae) were measured over time (after 3,5 and 7d). The species was very well adapted to the current salinity of the sampling region, as both algal $\mathrm{N}$ and $\mathrm{C}$ uptake was highest at a salinity of 20. It seems that $E$. excavatum coped better with lower than with higher salinities. The amount of absorbed $\mathrm{C}$ from the green algae $D$. tertiolecta showed a tendency effect of salinity, peaking at a salinity of 20. Nitrogen uptake was also highest at a salinity of 20 and steadily increased with time. In contrast, $\mathrm{C}$ uptake from the diatom $L$. arenaria was highest at a salinity of 15 and decreased at higher salinities. We found no overall significant differences in $\mathrm{C}$ and $\mathrm{N}$ uptake from green algae vs. diatoms. Furthermore, the food uptake at a light-dark rhythm of $16: 8 \mathrm{~h}$ was compared to continuous darkness. Darkness had a negative influence on algal $\mathrm{C}$ and $\mathrm{N}$ uptake, and this effect increased with incubation time. Starving experiments
\end{abstract}

showed a stimulation of food uptake after $7 \mathrm{~d}$. In summary, it can be concluded that $E$. excavatum copes well with changes of salinity to a lower level. For changes in light regime, we showed that light reduction caused a decrease of $\mathrm{C}$ and $\mathrm{N}$ uptake by E. excavatum.

\section{Introduction}

\subsection{General information}

Foraminifera are unicellular, highly diverse marine organisms known since the early Cambrian (e.g., Scott et al., 2003; Pawlowski et al., 2003). As major consumers of phytodetritus they play an important role in organic matter recycling in marine environments, particularly in marine sediments (benthos), from coasts to the deep sea and in brackish water (Boltovskoy and Wright, 1976). Most foraminifera are heterotrophic, but some can isolate functional chloroplasts from their algal food sources, keep them viable in their cells and incorporate them into their own cellular metabolism, a process termed kleptoplastidy (Bernhard and Bowser, 1999). Elphidium, a benthic foraminifer, is one of nine currently known genera of foraminifera (Bulimina, Elphidium, Haynesina, Nonion, Nonionella, Nonionellina, Reophax, Stainforthia and Virgulinella) which perform kleptoplastidy (Lopez, 1979; Lee et al., 1988; Cedhagen, 1991; Bernhard and Bowser, 1999; Correia and Lee, 2000; Grzymski et al., 2002; Goldstein et al., 2004; Pillet et al., 2011; Lechliter, 2014; Tsuchiya et al., 2015). Elphidium has a 
worldwide distribution and occurs from tropical to Arctic waters (Murray, 1991). This genus makes up a particularly high proportion of the total foraminiferal population in the shallow water of the Mediterranean, the English Channel, the North Sea and the Baltic Sea (Murray, 1991). More than 60 morphospecies of Elphidium are known (Murray, 1991), many of which are present in the North Sea and Baltic Sea. A detailed description of the different species and morphotypes is given in Darling et al. (2016). The most common species are E. albiumbilicatum, E. excavatum clavatum, $E$. excavatum excavatum, E. gerthi, E. guntheri, E. incertum and E. williamsoni (Weiss, 1954; Terquem, 1876; Williamson, 1858; Lutze, 1965; Frenzel et al., 2005; Nikulina et al., 2008; Polovodova and Schönfeld, 2008). Elphidium excavatum shows a large morphological intraspecific variability (Miller et al., 1982). Two subspecies of this foraminifer ( $E$. e. excavatum and E. e. clavatum) have been found to coexist in the Baltic Sea (Lutze, 1965). Schweizer et al. (2011) showed that these species exhibit large genetic differences with respect to each other and therefore can be regarded as subspecies rather than as ecophenotypes.

During longer periods of starvation, kleptoplasts may possibly serve as a nutritional source that can be digested (Falkowski and Raven, 2007). But they can also supplement the nutrition through photosynthesis under light conditions. Diatoms are the major chloroplast sources for Elphidium, with an average of $3.7 \times 10^{4}$ chloroplasts possessed by one foraminiferal individual (Correia and Lee, 2000). The retention time of functional chloroplasts in foraminifera may vary from several days to several months (Lopez, 1979; Lee et al., 1988; Correia and Lee, 2002). Another genus, Haynesina (Pillet at al., 2011), can sustain their kleptoplasts efficiently for more than a week (Jauffrais et al., 2016). The uptake of kleptoplasts by Haynesina germanica and Elphidium williamsoni through the consumption of diatoms can be seen in the comparison of spectral signatures and pigment composition (Jauffrais et al., 2016; 2019a). Further experiments showed that not all algae are excellent chloroplast donors (Lee and Lee, 1989; Correia and Lee, 2001). It was observed that Elphidium absorbs up to 5 times more chloroplasts from diatoms than from green algae (Correia and Lee, 2000). It was also pointed out that different light-dark regimes had no influence on the uptake of chloroplasts by Elphidium (Correia and Lee, 2000). Foraminifera below the photic zone can also perform kleptoplastidy (Bernhard and Bowser, 1999). These aspects suggest that foraminifera can not only incorporate chloroplasts for photosynthetic activity but may also benefit from other catabolic mechanisms (LeKieffre et al., 2018). This means these are not only $\mathrm{C}$ or $\mathrm{N}$ pathways; one of these mechanisms could also be the sulfur cycle (Jauffrais et al., 2019b). Recent studies showed that foraminifera host sulfur cycle bacteria which have the potential to act as endobionts (Salonen et al., 2019). Experiments showed that foraminifera can even use kleptoplasts to control the $\mathrm{pH}$ value in their cytoplasm (Tsuchiya et al., 2020). This leads to an increased intracellular $\mathrm{pH}$ environment which allows foraminifera to produce a high magnesian calcite test (Tsuchiya et al., 2020).

Currently little is known about the feeding behavior and the $\mathrm{C}$ and $\mathrm{N}$ metabolism of foraminifer species exhibiting kleptoplastidy, such as Elphidium or Haynesina. Moreover, given that plastids may either supplement the nutrition of foraminifera by providing photosynthates or by being digested, kleptoplastid species may show a slower detrimental response to starvation or a slower uptake of (pulses of) algal food (Lintner et al., 2020). Foraminiferal food uptake depends on several factors such as the size of food (Murray, 1963), type of food (e.g., Lee and Müller, 1973; Nomaki et al., 2014), age of the foraminifera and food quality (Lee et al., 1966), water temperature (Wukovits et al., 2017; Heinz et al., 2012), or salinity (Lintner et al., 2020; Dissard et al., 2009). Salinity and light conditions are highly variable in intertidal and brackish milieus where foraminifera thrive in highly diverse and active communities. Very little is known about such light-dark and salinity effects on the feeding behavior of foraminifera. For example, the kleptoplastid species Haynesina germanica showed no response to changes in salinity, while food uptake by the nonkleptoplastid species Ammonia tepida increased with salinity (Lintner et al., 2020). In the same study, both species showed large differences in the retention of $\mathrm{C}$ relative to $\mathrm{N}$, with subsequent adverse effects on the recycling of these elements by mineralization and respiration and excretion to the environment. Such differences, given that these species are (co)dominant in their foraminiferal community, can have important implications for local marine biogeochemical cycles of $\mathrm{C}$ and $\mathrm{N}$.

Based on the abovementioned aspects, this study investigated the food uptake and food preference (green algae vs. diatoms) of Elphidium excavatum spp. at different salinity levels and a changing light-dark rhythm. Elphidium excavatum is optimally suited for this purpose, as it is representative of foraminifera in coastal regions and can account for over $90 \%$ of the total foraminiferal population in some areas (Schönfeld and Numberger, 2007). After Darling et al. (2016) our used foraminifera (E. excavatum) are called E. selseyense. Actually E. selseyense is officially called Cribroelphidium selseyense. But due to the high importance of the "older" name we used for this paper the most common and more often cited name, E. excavatum.

\subsection{Sampling location Kiel Fjord}

Foraminifera studied here were collected in the Kiel Fjord in northern Germany. The Kiel Fjord covers $9.5 \mathrm{~km}$ in length. It is about $250 \mathrm{~m}$ wide in the south (inner fjord) and widens to the northern part to a width of $7.5 \mathrm{~km}$ (outer fjord) (Nikula et al., 2007; Polovodova and Schönfeld, 2008). The inner fjord is about $10-12 \mathrm{~m}$ deep, whereas the outer fjord has more than $20 \mathrm{~m}$ water depth. The water in the inner fjord is 
well homogenized and has a relatively constant temperature and salinity at any depth (Schwarzer and Themann, 2003). During the summer months stratification of water masses occurs, with the surface water having a temperature of $16^{\circ} \mathrm{C}$ and a salinity of 14 and the bottom water having a temperature $12^{\circ} \mathrm{C}$ and a salinity of 21 (Nikula et al., 2007; Polovodova and Schönfeld, 2008). In the southeast of the fjord, a fresh water supply, the Schwentine, contributes to a lower salinity of water in this area. Earlier investigations showed that occasional seawater inflow from the Baltic Sea (very saline surface water with a salinity of 33) has no major impact on the hydrography in the Kiel Fjord (Fennel, 1996). The most common sediments in the fjord are fine sand and dark, organic-rich mud (especially found in the inner fjord). In this area corrosion (abrasion and redeposition) of foraminiferal tests plays an important role, due to the undersaturation of carbonate in the surface water (Grobe and Fütterer, 1981).

\section{Materials and methods}

\subsection{Sample collection and culturing}

The samples were collected from the Kiel Fjord in northern Germany on 26 and 27 September 2018 with a box corer on the research vessel FS ALKOR. Detailed data on sampling sites are given in Table 1. The light penetration depth of this

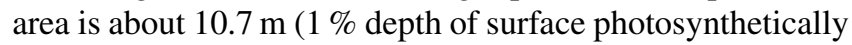
active radiation, Rohde et al., 2008). On board the research vessel, the upper $5-7 \mathrm{~cm}$ of the box corer sediments were wet-sieved through a 63 or $125 \mu \mathrm{m}$ sieve and kept in storage containers with seawater from the sampling site until arrival at the laboratory at the University of Vienna (29 September 2018). The permanent cultures (glass tubes covered with thin foil against evaporation) were kept at a constant temperature of $20^{\circ} \mathrm{C}$ (room temperature) and at a salinity of 20 in the laboratory.

\subsection{Preparation of the labeled food source}

Feeding experiments were performed with the green algae Dunaliella tertiolecta and the benthic diatom Leyanella arenaria as food sources. These algae were often used in other feeding experiments with foraminifera; therefore we can assume that they would also be consumed by E. excavatum. A $f / 2$ nutrient medium (Guillard and Ryther, 1962; Guillard, 1975), enriched with the isotopes ${ }^{13} \mathrm{C}$ and ${ }^{15} \mathrm{~N}$ by amendment to a level of $1.5 \mathrm{mmolL}^{-1} \mathrm{NaH}^{13} \mathrm{CO}_{3}$ and $0.44 \mathrm{mmolL}^{-1} \mathrm{Na}^{15} \mathrm{NO}_{3}$, was prepared for both cultures. The algal cultures were kept at $20^{\circ} \mathrm{C}$ and a light-dark rhythm of $16: 8 \mathrm{~h}$ in an isotopically enriched medium. Dunaliella tertiolecta was harvested at peak biomass, when the cultures showed a strong green color. Leyanella arenaria was harvested as soon as the bottom of the mixing vessel was densely populated and had a homogenous brown color. These two states reflect the characteristics of an optimal culture, where the algae are consumed later preferentially by foraminifera (Lee et al.. 1966). To collect isotopically enriched algae, the cultures were centrifuged at $800 \times g$ for $10 \mathrm{~min}$. The resultant algal pellet was washed three times with artificial seawater (Enge et al., 2011) and centrifuged after each washing step. Afterwards, the algal pellet was shock-frozen in liquid nitrogen and lyophilized for $3 \mathrm{~d}$ at $0.180 \mathrm{mbar}$. In order to retain a high quality of food, the dried algae were stored in a dry and dark place until use. The labeled algal powder was isotopically enriched by about 3.3 at. $\%{ }^{13} \mathrm{C}$ and 32.3 at. $\%{ }^{15} \mathrm{~N}$ for D. tertiolecta and about 12.6 at. $\%{ }^{13} \mathrm{C}$ and 17.9 at. $\%{ }^{15} \mathrm{~N}$ for $L$. arenaria. The $\mathrm{C}: \mathrm{N}$ ratios based on $\mathrm{C}$ and $\mathrm{N}$ content of the diatom and the green algal food source were 9.14 for $L$. arenaria and 5.78 for D. tertiolecta, respectively.

\subsection{Feeding experiments}

Before the start of the experiments ( $4 \mathrm{~d}$ after sampling of the material) all glassware was cleaned in a muffle furnace $\left(500^{\circ} \mathrm{C}\right.$ for $\left.5 \mathrm{~h}\right)$. The "picking tools" and tin capsules were cleaned with a $1: 1(v: v)$ mixture of dichloromethane $\left(\mathrm{CH}_{2} \mathrm{Cl}_{2}\right)$ and methanol $\left(\mathrm{CH}_{3} \mathrm{OH}\right)$.

A total of 20 foraminifer specimens $(>150 \mu \mathrm{m}$ E. excavatum S5 after Darling et al., 2016, see Fig. 1) were collected from the permanent cultures using small brushes and placed in a crystallization dish with $280 \mathrm{~mL}$ sterile filtered seawater from the sampling site in triplicates for the different time points and experiments. For the experiments we picked only foraminifera for which tests were fully filled with brownish cytoplasm. The food source was added once at the beginning of the experiments (in the case of point iv the food was added after the starving period). After the experiments, there was still enough food at the bottom of the dishes, which indicated that there was sufficient food available during the whole experiment. Triplicates were analyzed for each time point and parameter (time, salinity, food source or light condition).

i. Salinity. To test the influence of salinity and time on food uptake, the original seawater (salinity of 20) was adjusted by adding $\mathrm{NaCl}$ or distilled water to obtain the desired salinity level $(15,20$ and 25). These salinities correspond to different areas of the Kiel Fjord (salinities of 15 at the Schwentine estuary, 20 at the sampling location Strander Bucht and Laboe, and 25 at the outer fjord). Subsequently, foraminifera were incubated for $24 \mathrm{~h}$ at $20^{\circ} \mathrm{C}$ with a $16: 8 \mathrm{~h}$ light-dark (30 $\mu$ mol photons $\mathrm{m}^{-2} \mathrm{~s}^{-1}$ ) cycle without food addition to acclimate to the new parameters, before the labeled D. tertiolecta food ( $5 \mathrm{mg}$ ) was added. Food uptake was measured after 3,5 and $7 \mathrm{~d}$.

ii. Food preference. The second experiment investigated the effect of different algal food sources on food uptake of the foraminifer species. For this, the green algae D. tertiolecta $(5 \mathrm{mg})$ and the diatom L. arenaria 
Table 1. Information of the sampling points. 1: Strander Bucht, 2: Laboe.

\begin{tabular}{lrrrrr}
\hline Sample & $\mathrm{N}$ & $\mathrm{E}$ & Depth $(\mathrm{m})$ & $T\left({ }^{\circ} \mathrm{C}\right)$ & Salinity (unitless) \\
\hline Strander Bucht & $54^{\circ} 25.998^{\prime}$ & $010^{\circ} 11.105^{\prime}$ & 16.3 & 14.8 & 20.9 \\
Laboe & $54^{\circ} 25.235^{\prime}$ & $010^{\circ} 12.409^{\prime}$ & 15.3 & 14.9 & 20.9 \\
\hline
\end{tabular}

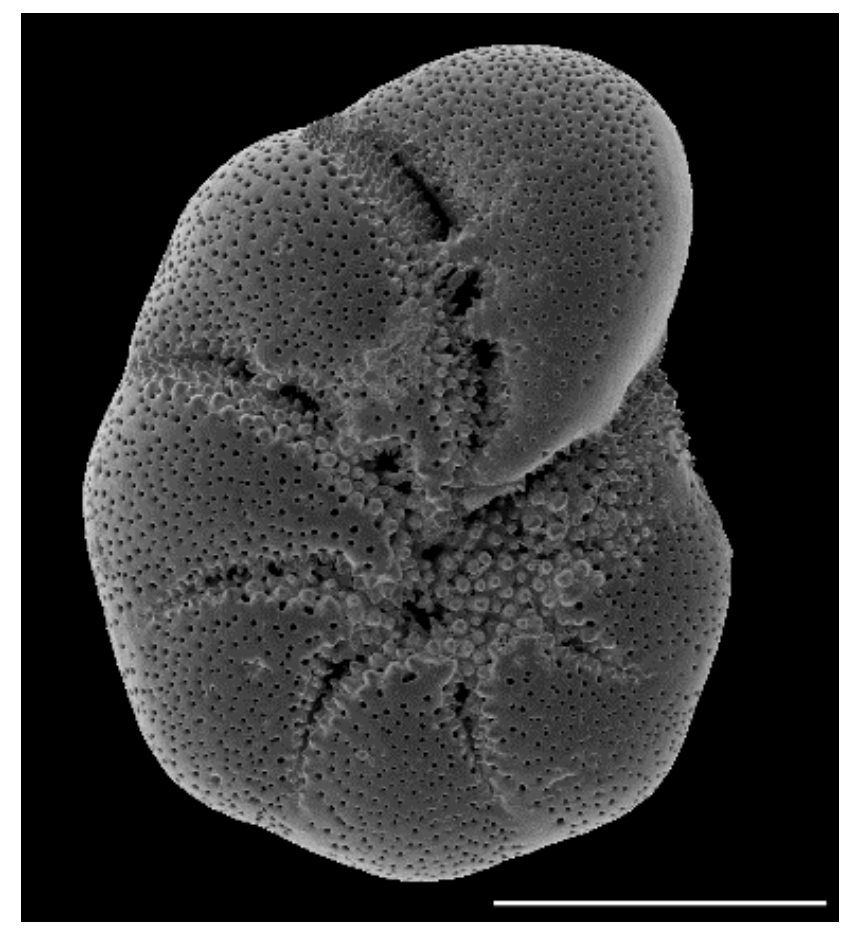

Figure 1. SEM (scanning electron microscope) picture of the incubated foraminifera E. excavatum S5 after Darling et al. (2016). Bar scale is $100 \mu \mathrm{m}$.

$(5 \mathrm{mg})$ were offered to foraminifera at salinities of 15,20 and 25 and a light-dark rhythm of $16: 8 \mathrm{~h}$ $\left(30 \mu \mathrm{mol}\right.$ photons $\left.\mathrm{m}^{-2} \mathrm{~s}^{-1}\right)$ and specimens collected after $5 \mathrm{~d}$.

iii. Light. The third experiment tested the effect of different light conditions on food uptake (only D. tertiolecta food, $5 \mathrm{mg}$ ). Here, foraminifera were acclimatized $24 \mathrm{~h}$ before food addition to continuous darkness or a $18: 6 \mathrm{~h}$ light-dark cycle $\left(30 \mu \mathrm{mol}\right.$ photons $\left.\mathrm{m}^{-2} \mathrm{~s}^{-1}\right)$, at $20^{\circ} \mathrm{C}$ and a salinity of 20 , and samples were collected after $1,3,5$ and $7 \mathrm{~d}$.

iv. Starvation. In order to determine the starvation effect on food uptake of this species, foraminifera were cultured in the dark without nutritional supplement for different periods of time $(1-7 \mathrm{~d})$, at $20^{\circ} \mathrm{C}$ and a salinity of 20 , and then were fed for $24 \mathrm{~h}$ with $5 \mathrm{mg} \mathrm{D}$. tertiolecta.

At the end of the test period, foraminifera were picked from the crystallization dishes, and any food residues were removed from the tests. Afterwards, they were washed three times with distilled water. It should be mentioned that this process could lead to a loss of cytoplasm due to osmotic shock. Therefore, the washing process should be done carefully and quick to avoiding a breakup of the tests, which we did not observe during our experiments. Generally, we used always the same amount of distilled water, so they were all treated in the same way. So far, any impact of using distilled water has the same effect on all samples. For isotope analysis, 20 foraminifera were transferred into pre-weighted clean tin capsules ( $\mathrm{Sn}$ 99.9, IVA Analysentechnik $\mathrm{GmbH}$ $\&$ Co. KG) and dried for $3 \mathrm{~d}$ at room temperature. Finally, $5 \mu \mathrm{L}$ of $4 \% \mathrm{HCl}$ was added twice to dissolve carbonate from foraminiferal tests. The dissolution was carried out at $60^{\circ} \mathrm{C}$ in a drying oven. Before weighing and isotope analysis, the tin capsules were dried again at $60^{\circ} \mathrm{C}$ for $24 \mathrm{~h}$ to remove any residual moisture. The dried and weighed samples were stored in a desiccator until isotope measurements.

\subsection{Isotope analysis}

Isotope analysis was performed at the Stable Isotope Laboratory for Environmental Research (SILVER) at the University of Vienna. Ratios of ${ }^{13} \mathrm{C} /{ }^{12} \mathrm{C}$ and ${ }^{15} \mathrm{~N} /{ }^{14} \mathrm{~N}$ were recorded by isotope ratio mass spectrometry (IRMS) using an elemental analyzer (EA 1110, CE Instruments) coupled with an interface (ConFlo III, Thermo Scientific) to a Delta ${ }^{\text {PLUS }}$ IRMS (Thermo Scientific).

In order to determine the amount of absorbed $\mathrm{C}$ or $\mathrm{N}$ the at. \% was calculated according to

at. $\%=\frac{100 \times R_{\text {standard }} \times\left(\frac{\delta X_{\text {sample }}}{1000}+1\right)}{1+R_{\text {standard }} \times\left(\frac{\delta X_{\text {sample }}}{1000}+1\right)}$,

where $X$ stands for $\mathrm{C}$ or $\mathrm{N}$ here and $R_{\text {Standard }}$ is Vienna Pee Dee Belemnite $R_{\mathrm{VPDB}}$ of 0.0112372 for $\mathrm{C}$ and is atmospheric nitrogen $R_{\text {atmN }}$ of 0.0036765 for $\mathrm{N}$.

Since the heavy stable isotopes used as a tracer $\left({ }^{13} \mathrm{C}\right.$ and ${ }^{15} \mathrm{~N}$ ) are also occurring naturally, the natural abundance of these isotopes needs to be accounted for which was measured in foraminifera (untreated specimens from the main culture) that did not obtain labeled algal food sources. To take this into account, the so-called isotope excess $(E)$ is calculated (Middelburg et al., 2000):

$$
E=\frac{\text { atom } X_{\text {sample }}-\text { atom } X_{\text {background }}}{100} \text {. }
$$


As $X_{\text {background }}$ isotope abundances of foraminifera were used, they were not fed and thus reflect the natural isotope abundance signal.

The absorbed amount of isotopes can now be quantified, i.e., labeled $I_{\text {iso }}$ for incorporated $\mathrm{C}$ or $\mathrm{N}$.

$$
I_{\text {iso }} \mu \mathrm{g} \mathrm{mg}^{-1}=E \times \mathrm{C}(\mathrm{N}) \mu \mathrm{g} \mathrm{mg}^{-1}
$$

Here, either the number of individuals (per individual) or the mass (dry matter without test, see Sect. 3.1.) of foraminifera were used as reference.

Finally, we need to consider the different isotopic enrichment of the algal food sources. Thus, "phytodetrital carbon" $(\mathrm{pC})$ or "phytodetrital nitrogen" $(\mathrm{pN})$ is calculated accounting for the isotopic enrichment of the food sources. These values are calculated as follows:

$p X=\frac{I_{\text {iso }}}{\frac{\text { at. } \% X_{\text {phyto }}}{100}}$.

\subsection{Statistics}

To test the main effects of salinity, food source, time, lightdark cycles, and starvation on $\mathrm{pC}$ and $\mathrm{pN}$ uptake we applied Kruskal-Wallis tests with a confidence interval of $95.0 \%$. All statistical tests were performed using Statgraphics Centurion XVI. The points in the graphs are the mean values from triplicates, with a $2 \sigma$ error bar for the standard deviation.

\section{Results}

\subsection{Effect of salinity and time on $\mathrm{C}$ and $\mathrm{N}$ uptake from green algal food}

The uptake of $\mathrm{C}(\mathrm{pC})$ and $\mathrm{N}(\mathrm{pN})$ from green algal food sources by $E$. excavatum was slightly affected by salinity (Fig. 2). The statistical evaluation (Kruskal-Wallis) showed a significant effect of salinity on $\mathrm{pC}(p=0.050)$ but no significant effect of time $(p=0.651)$. For a better insight into the described results, all data (values) are given in the Supplement. pC tended to be highest at a salinity of 20 , followed by 25 and 15 across the whole time series. Considering the mean values after $3 \mathrm{~d}$ of feeding, E. excavatum showed the lowest $\mathrm{pC}$ values at salinities of 15 and 25 . The uptake of $\mathrm{C}$ showed a different pattern after $5 \mathrm{~d}$ and here reached a maximum at a salinity of 20 , while the values at salinities 15 and 25 were lower but similar. After $7 \mathrm{~d}$ the amount of incorporated $\mathrm{C}$ was approximately the same at all three salinities (15, 20 and 25).

The amount of absorbed nitrogen $(\mathrm{pN})$ was highly significantly affected by salinity $(p=0.004)$, though it was not by time $(p=0.589)$. At salinities of 15 and $20 \mathrm{~N}$ uptake (mean values) increased steadily from 3 to $7 \mathrm{~d}$, while at a salinity of $25 \mathrm{~N}$ uptake remained constant between 3 and $5 \mathrm{~d}$ and thereafter decreased. The values of $\mathrm{pN}$ were very similar after $3 \mathrm{~d}$. This changed after $5 \mathrm{~d}$, where the highest amount of $\mathrm{pN}$ was determined at a salinity of 20 , while $\mathrm{N}$ uptake was approximately the same at salinities of 15 and $25(p<0.1)$. The pattern of $\mathrm{pN}$ at this time point $(5 \mathrm{~d})$ is highly comparable with the $\mathrm{C}$ uptake pattern. With increasing incubation time, the $\mathrm{pN}$ values differed significantly. After $7 \mathrm{~d}(p<0.01)$, the maximum of $\mathrm{pN}$ was observed at a salinity of 20 and was much lower at salinities of 15 and 25 .

\subsection{Effect of food source (green algae and diatoms) and salinity on $\mathrm{C}$ and $\mathrm{N}$ uptake}

The values of $\mathrm{C}$ and $\mathrm{N}$ uptake from different food sources at three salinity levels are listed in Fig. 3.

Kruskal-Wallis test results of the $\mathrm{C}$ uptake showed no significant difference $(p=0.825)$ between the offered food sources. However, this main salinity effect differed by food source: $\mathrm{pC}$ from $D$. tertiolecta peaked at a salinity of 20 , while $\mathrm{pC}$ from $L$. arenaria was highest at a salinity of 15 and showed a sharp decrease at higher salinities.

Nitrogen uptake showed quite different patterns compared to $\mathrm{C}$ uptake. We found a highly significant difference in $\mathrm{pN}$ between food sources $(p=0.004)$. In contrast to $\mathrm{pC}$, $\mathrm{pN}$ was significantly higher after feeding on green algae than on diatoms. Otherwise, food-specific effects of salinity on $\mathrm{pN}$ followed those of $\mathrm{pC}$; i.e., $\mathrm{pC}$ peaked at a salinity of 20 for $D$. tertiolecta and was highest at a salinity of 15 for L. arenaria.

Comparing the salinity effects on incorporated $\mathrm{C}$ and $\mathrm{N}$ from feeding with $D$. tertiolecta with those of $L$. arenaria, different trends can be deduced. The highest $\mathrm{pC}$ was reached at the lowest salinity (15) from the diet with L. arenaria, while at the highest salinity (25) the $\mathrm{C}$ uptake was highest when fed with $D$. tertiolecta. In contrast, $\mathrm{N}$ was preferentially incorporated from a diet with $D$. tertiolecta. Such differences in $\mathrm{pC}$ and $\mathrm{pN}$ from different algal sources were also reflected in distinct ratios of $\mathrm{pC}: \mathrm{pN}$, which were $2.2-2.7$ in D. tertiolecta and 6.4-7.5 in L. arenaria.

\subsection{Effects of the light regime on the uptake of $\mathrm{C}$ and $\mathrm{N}$ from green algal food}

The experiments clearly showed a strong effect of the light regime on the food uptake of $E$. excavatum, with $D$. tertiolecta as the food source (Fig. 4). Kruskal-Wallis test results of these data showed that the light regime had a highly significant effect on $\mathrm{pC}$ of $E$. excavatum $(p<0.001)$, while time $(p=0.561)$ was not significant. Continuous darkness caused a sizable reduction of $\mathrm{pC}$ compared to $16: 8 \mathrm{~h}$ light-dark cycles.

The negative effect of continuous darkness was also observable on $\mathrm{pN}(p=0.102)$. Despite this negative effect, $\mathrm{pN}$ tended to increase with time ( $p=0.058)$, particularly so under $16: 8 \mathrm{~h}$ light-dark cycles. 

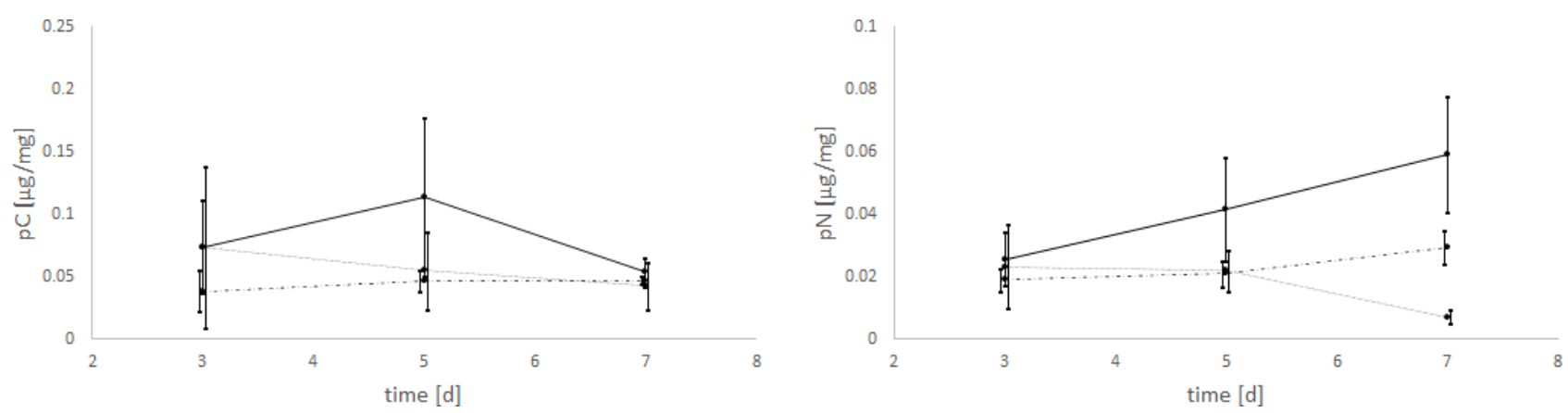

Figure 2. Salinity effects on the uptake of $\mathrm{C}(\mathrm{pC})$ and $\mathrm{N}(\mathrm{pN})$ from the green algae D. tertiolecta by E. excavatum after different feeding times at $20^{\circ} \mathrm{C}$ and a light-dark cycle of $18: 6 \mathrm{~h}$.
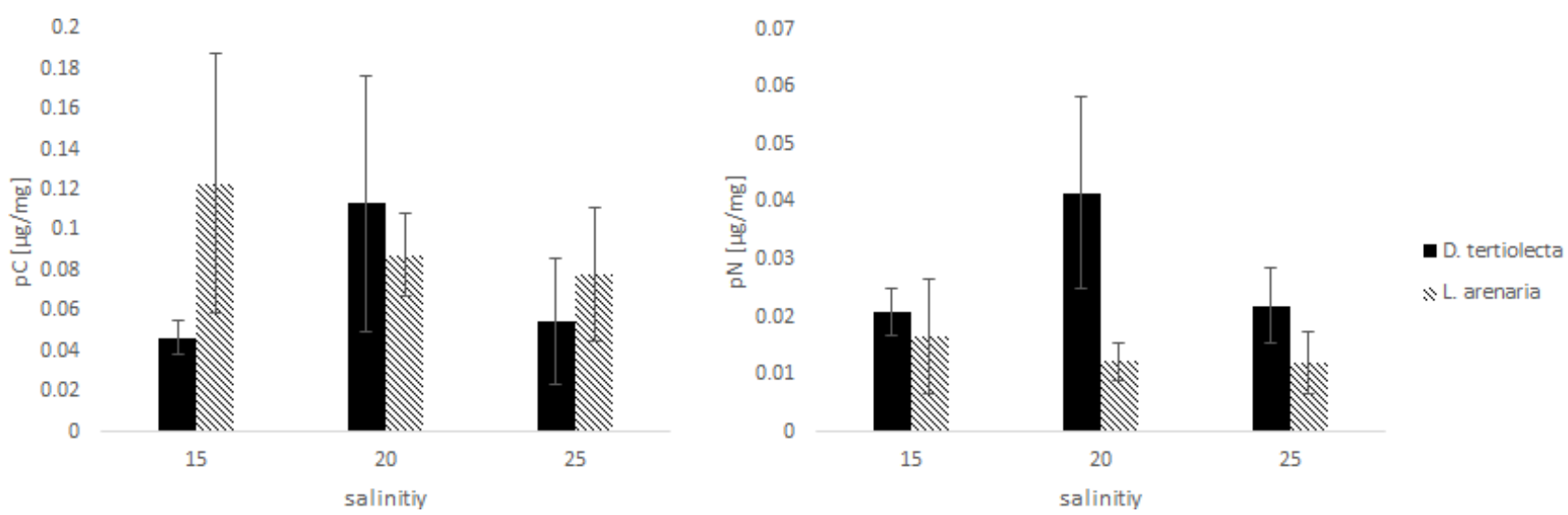

Figure 3. The uptake of $\mathrm{C}(\mathrm{pC})$ and $\mathrm{N}(\mathrm{pN})$ from different food sources (the green algae $D$. tertiolecta and the diatom $L$. arenaria) by $E$. excavatum after $5 \mathrm{~d}$ at $20^{\circ} \mathrm{C}$ and a light-dark cycle of $16: 8 \mathrm{~h}$.

\subsection{Effects of starvation on the uptake of $\mathrm{C}$ and $\mathrm{N}$ from green algal food}

In a fourth experiment, foraminifera were incubated for different time intervals $(1,3,5$ and $7 \mathrm{~d})$ without any food in the darkness. After each starvation period they were fed with $D$. tertiolecta and exposed to light for $24 \mathrm{~h}$.

Considering the positive slope of the correlation line for the mean values (pC: $k=0.0041, \mathrm{pN}: k=0.0019$ ), it seems that the longer the foraminifera were starved, the more food was consumed within $24 \mathrm{~h}$ (Fig. 5). However, Kruskal-Wallis test results showed no significant starvation time effect of $\mathrm{C}$ uptake ( $p=0.223)$, but there was a tendency increase in $\mathrm{pN}$ with increasing starvation duration $(p=0.113)$. During the first $5 \mathrm{~d}$ in darkness without food, there was hardly any difference in $\mathrm{N}$ uptake, while after $7 \mathrm{~d}$ in darkness a clear increase of $\mathrm{pN}$ was recorded. Similarly, $\mathrm{pC}$ tended to be stimulated by prolonged starvation, but the variation was too high to become significant.

\section{Discussion}

\subsection{Food uptake of E. excavatum at different salinities and type of food}

Salinity $(15,20$ and 25$)$ significantly affected the food uptake of E. excavatum, especially for longer test times. The low level of ingested $D$. tertiolecta in comparison to other studies with Ammonia tepida $\left(0.4-1.2 \mu \mathrm{g} \mathrm{mg}^{-1}\right.$ and 0.2 $0.4 \mu \mathrm{g} \mathrm{N} \mathrm{mg}^{-1}$ at a salinity of 24) and Haynesina germanica $\left(0.05-0.35 \mu \mathrm{g} \mathrm{C} \mathrm{mg}{ }^{-1}\right.$ and $0.03-0.13 \mu \mathrm{g} \mathrm{N} \mathrm{m}^{-1}$ at a salinity of 24) (Lintner et al., 2020; Wukovits et al., 2017) suggests that this green algae was not a preferred dietary source of this foraminifer species. This observation can be compared with experiments by Correia and Lee (2000) which demonstrated an increased absorption of chloroplasts by E. excavatum, which corresponds to a dietary preference for diatoms. Though the amount of ingested $\mathrm{C}$ from the diatom $L$. arenaria was also low here, we found a tendency preference of E. excavatum for the diatom diet over the green algal diet. It is therefore likely that E. excavatum prefers the algal diet that corresponds to the source of its kleptoplasts. Moreover, generally food (C) uptake by a kleptoplastid species $(H$. german- 

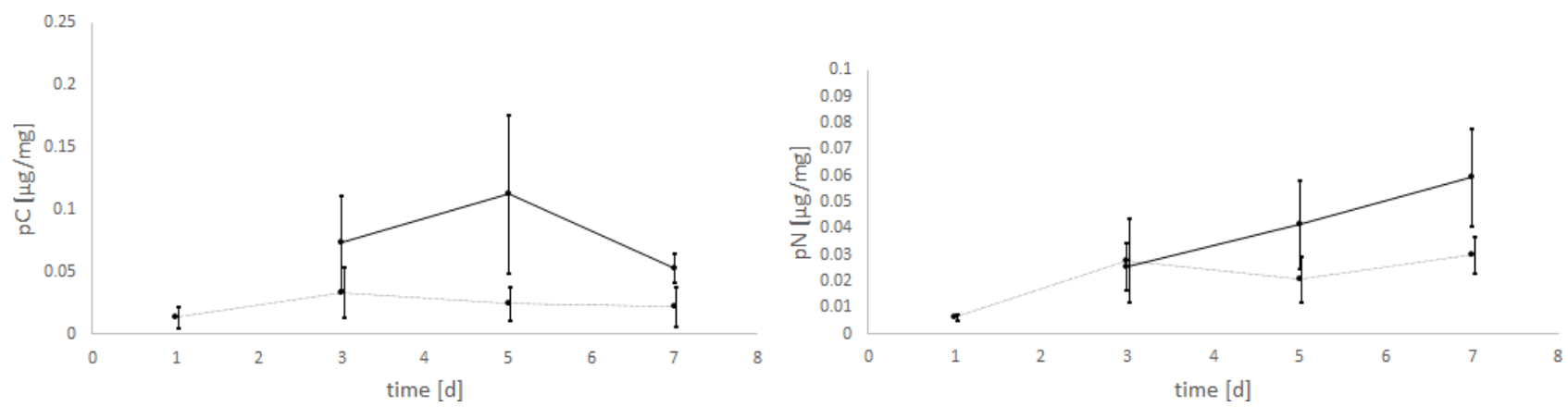

Figure 4. Effects of the light regime (light-dark cycle of $18: 6 \mathrm{~h}$ vs. continuous darkness) on the uptake of $\mathrm{C}(\mathrm{pC})$ and $\mathrm{N}(\mathrm{pN})$ from the green algae D. tertiolecta by E. excavatum after different feeding times at $20^{\circ} \mathrm{C}$ and a salinity of 20 . The values of the "light experiments" are the same as used in Fig. 2.
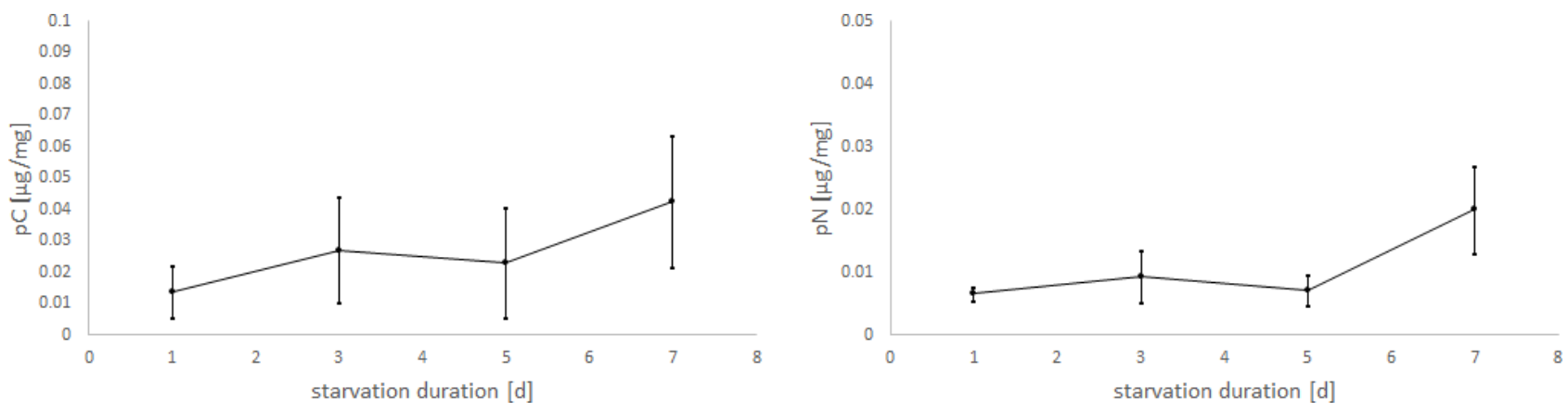

Figure 5. Uptake of $\mathrm{C}(\mathrm{pC})$ and $\mathrm{N}(\mathrm{pN})$ from green algal food (D. tertiolecta) by E. excavatum after different starvation periods in the dark at a salinity of 20 and $20^{\circ} \mathrm{C}$.

$i c a$ ) was lower than that of a species not showing kleptoplastidy (A. tepida) (Lintner et al., 2020; Wukovits et al., 2017), indicating that the chloroplasts can supplement the $\mathrm{C}$ nutrition of species exhibiting kleptoplastidy. A shift of C uptake from diatoms at a salinity of 15 to green algae at salinities of 20-25 is also noteworthy and has not yet been observed in this or other foraminifer species. This might have strong implications on foraminiferal $\mathrm{C}$ and $\mathrm{N}$ recycling in habitats where E. excavatum is dominant, given that $\mathrm{N}$ retention was approximately 3-fold higher with diets of green algae compared to diatoms ( $\mathrm{pC}: \mathrm{pN}$ was $2.2-2.7$ for $D$. tertiolecta compared to 6.4-7.5 for L. arenaria).

On a closer look, it can be seen that foraminifera reacted to an increased salt content in the longer term by lower rates of green algal food consumption. The mean $\mathrm{C}$ uptake recorded at a salinity of 20 showed a maximum $5 \mathrm{~d}$ after food addition and declined thereafter. Such a behavior is already known from $H$. germanica (Lintner et al., 2020), a closely related species living in the same habitat. In Lintner et al. (2020) this behavior was explained by the fact that $H$. germanica also contained kleptoplasts, which may serve as internal $\mathrm{C}$ and $\mathrm{N}$ sources via digestion. In the case of foraminiferal $\mathrm{N}$ uptake in our study, this effect was not evident, as the amount of incorporated $\mathrm{N}$ increased steadily, at least at salinities of 15 and 20. At this point it should be noted that foraminifera metab- olize food $\mathrm{C}$ and $\mathrm{N}$ during their digestive process and release them into the surrounding environment as excreta or as respiratory $\mathrm{CO}_{2}$ (Hannah et al., 1994; Nomaki et al., 2014). This needs to be taken into account the longer an experiment lasts and might explain the decrease in the incorporated amount of $\mathrm{C}$ from day 5 to 7 (Fig. 2). Although $\mathrm{C}$ is constantly being absorbed by foraminifera in the form of food, it is also partially relocated and excreted or released by cellular respiration (Hannah et al., 1994). Furthermore, C can also be used for test formation as shown in the study of LeKieffre et al. (2017). During the preparation of foraminifera for isotope analysis, the test is dissolved in hydrochloric acid, and the amount of incorporated $\mathrm{C}$ in the test is not measured, which may cause an underestimation of $\mathrm{pC}$ relative to $\mathrm{pN}$ at prolonged feeding times. Although $\mathrm{N}$ can also be transferred into various excretions and released into the surrounding water in organic and inorganic form, a large part still remains in the form of proteins or amino acids in the cell of the organisms (Nomaki et al., 2014).

After $3 \mathrm{~d}$, foraminifera showed minimum $\mathrm{C}$ uptake at the lowest salinity (15). Comparing the entire time series of green algal uptake, the series for a salinity of 15 is the only one with a positive slope of mean values $(k=0.0021)$ for $\mathrm{pC}$ with time. Based on this observation, foraminifera might feel uncomfortable at low salinities and react to this with 
a reduced metabolism. There are a few studies which discuss the reduction of metabolism due to stressful conditions (Bernhard and Alve, 1996; Ross and Hallock, 2016; LeKieffre et al., 2017). This may lead to a generally lower activity of foraminifera, which reduces their cell respiration and results in a lower $\mathrm{C}$ output. This reduced $\mathrm{C}$ output could be linked to the accumulation of lipid droplets which seems to be a common response of benthic foraminifera in response to stressful conditions such as anoxia or increased heavy metal concentrations (Le Cadre and Debenay, 2006; Frontalini et al., 2016; 2015; Koho et al., 2018). Foraminifera held at a higher salinity (20 or 25) may have a higher activity and thus a greater $\mathrm{C}$ output due to cell respiration and excretion. The combination of these aspects could explain the negative slopes or peaks of the trend lines for a salinity of 20 and 25. Direct observations during the experiments showed that foraminifera cultured in crystallization dishes at salinities of 20 or 25 were more mobile (personal observation of crawling observations) than those at a salinity of 15 . This aspect confirms the higher activity of foraminifera at higher salinities.

The results of $\mathrm{N}$ incorporation differed from those of $\mathrm{C}$. Here, both the 15 and 20 salinity series showed a positive slope with time, while in the long term, less $\mathrm{N}$ was absorbed at higher salinities (25). The magnitude of the slope of the series for a salinity of 15 was markedly lower than that at a salinity of 20. Again, this could be due to the lower activity of foraminifera at a salinity of 15 compared to experiments at a salinity of 20. However, the decrease of $\mathrm{N}$ at a salinity of 25 with time cannot be explained so easily. A possible explanation is faster $\mathrm{N}$ metabolism coupled to increased excretion of $\mathrm{N}$-containing substances by foraminifera at a high salinity. There are no other studies which deal with these arguments, so further experiments are necessary to resolve this observation. Moreover, the combination of high salinity with an inappropriate diet (green algae) could cause long-term stressrelated damage to the cells. Overall, this experiment highlighted that the digestion and metabolic pathways of $\mathrm{C}$ and $\mathrm{N}$ differ substantially and are differentially influenced by environmental parameters in foraminifera (Lintner et al., 2020; Wukovits et al., 2017).

\subsection{Influence of the light-dark rhythm and starvation on the food uptake of $E$. excavatum}

Food uptake was affected by light conditions (see Fig. 4). Foraminifera had a much lower $\mathrm{C}$ and $\mathrm{N}$ uptake during continuous darkness. $\mathrm{pC}$ values were low and more or less constant from day 1 through to day $7(p=0.547)$. However, $\mathrm{N}$ uptake increased slightly under dark conditions. As already mentioned, Elphidium species possess chloroplasts (kleptoplasts), which they incorporate from their food sources into their own metabolic cycle (Correia and Lee, 2000). This aspect could be an important contribution to explain the light regime effects on food uptake rates. There are two different explanations.
First, in complete darkness foraminifera could stop foraging and start feeding on their "own" chloroplasts. Past investigations showed that chloroplasts in Elphidium were exclusively derived from diatoms, making diatoms their preferred food source (Pillet et al., 2011). Our experiments showed that E. excavatum had a significantly higher food uptake after $7 \mathrm{~d}$ of starvation compared to the days before (Fig. 5). During the first $5 \mathrm{~d}$, foraminifera may have either stagnated with a reduced metabolism, or they may have begun to digest their chloroplasts. For further investigations it would be interesting to detect chlorophyll in foraminifera spectroscopically, since this molecule is found exclusively in chloro- or kleptoplasts (Cevasco et al., 2015; Krause and Weis, 1991; Mackinney, 1941). One aspect to be discussed here is the lifetime of (viable) kleptoplasts in foraminifera under natural conditions. For example, Nonionella labradorica showed a strong seasonal variation in plastid viability (Cedhagen, 1991). According to Cedhagen (1991) specimens of $N$. labradorica collected in February were yellowish and showed no photosynthetic activity. In contrast, individuals sampled after the spring bloom in March or April were completely green and photosynthetically active. In a study by Cevasco (2015) foraminifera still contained chlorophyll ( $>288$ photosynthetic plastids) after being held $5 \mathrm{~d}$ without food in the darkness. The experiments by Lopez (1979) showed that $E$. williamsoni needs to ingest 65 chloroplasts per hour per individual in order to keep a constant number of chloroplasts in the cell. At the moment there is no study which has shown that the chloroplasts in E. excavatum are photosynthetically active. Lopez (1979) showed that there is no light-induced uptake of inorganic $\mathrm{C}$ by chloroplasts in E. excavatum. It should be noted that the aspect of difference in color mentioned by Cedhagen (1991) is probably also applicable to our foraminifera. Specimens of Elphidium for this study were collected in September, living in the top few centimeters of the sediment, and showed a yellow coloring. It can therefore be assumed that these individuals contained fewer functional chloroplasts from the beginning onwards compared to those in the study by Lopez (1979). The different residence times of kleptoplasts in foraminifera can be fundamentally explained by different feeding and sequestration strategies as well as diverse digestion abilities (Jauffrais et al., 2018).

Secondly, different food uptake rates under dark or light conditions by E. excavatum in this study could be explained by indirect light effects on chloroplasts in the foraminiferal cells. This aspect is rather speculative and needs of course further research to clarify. This raises the question whether inactive chloroplasts are degraded or stored for some time in order to be able to reactivate them. Furthermore, it is interesting to know whether E. excavatum, which lives in a suboxic milieu like the Kiel Fjord, possesses chloroplasts for acquiring oxygen from chloroplast photosynthesis in order to sustain respiratory metabolism of their mitochondria. This in turn leads to the question whether E. excavatum is vi- 
able without chloroplasts or whether the metabolism works in the long term only with this additional organelle. To answer these questions clearly further experiments are needed.

According to Jauffrais et al. (2016) the number of chloroplasts in $H$. germanica during starvation periods strongly depends on illumination conditions. Based on this, foraminifera with kleptoplastidy are more likely to lose active chloroplasts at light-exposed circumstances (Jauffrais et al., 2016). Combined with the results of Lopez (1979), who stated that foraminifera must obtain a certain number of chloroplasts from food to maintain a constant number in their cells, our experiments showed the following: E. excavatum is expected to be in a dormant phase under dark conditions, which entails limited food uptake (Fig. 4). After prolonged starving periods ( $>7 \mathrm{~d}$ ) in the dark, a starvation effect of this species is noticeable (Fig. 5). The triggers for this effect are currently unknown. It seems that E. excavatum can survive in the darkness from the previously ingested food for up to $5 \mathrm{~d}$ of starvation. Only after $7 \mathrm{~d}$ of starvation a significantly higher food uptake was observed.

\subsection{The influence of salinity and food source on the foraminiferal assemblages in the Kiel Fjord}

In line with the observations of Lee and Müller (1973) dietary sources used in our experiments had a tendency effect on $\mathrm{C}$ uptake, with higher $\mathrm{C}$ uptake from the diatom food. The effect of food type was even more pronounced for $\mathrm{N}$ uptake, with clearly higher incorporation rates of $\mathrm{N}$ from the green algal food. However, different salinity levels caused significant differences with time. Since E. excavatum is one of the dominant species in the Kiel Fjord (Schönfeld and Numberger, 2007) and thus plays an important role in the turnover of organic matter, this aspect is discussed in more detail here.

The Baltic Sea had several transgressive phases that play crucial roles in salinity changes (Robertsson, 1990; Jensen et al., 1997). The most important salinity indicators in this region are diatoms (Bak et al., 2006; Witkowski, 1994; Abelmann, 1985). Since diatoms serve as the natural food source for $E$. excavatum examined here, their salinity-based distribution plays an essential role in the interpretation of our results. A study by Schönfeld and Numberger (2007) demonstrated the close connection between foraminifera and diatoms. Their study showed that a few days after a phytoplankton bloom of diatoms a large depositional pulse of organic matter occurred, whereupon the population of $E$. excavatum increased 2-6-fold. In our experiments we found a slight preference of $E$. excavatum for the tested diatoms ( $L$. arenaria) over green algae (D. tertiolecta). Previous experiments showed how certain foraminifera are stimulated particularly by specific food sources (Lee et al., 1961). However, considering the small amount of incorporated $\mathrm{C}$ and $\mathrm{N}$ in our experiments, neither $L$. arenaria nor $D$. tertiolecta belongs to the preferred food sources of E. excavatum.
The Baltic Sea is the largest brackish water basin in the world (Voipio, 1981). During the sampling, the salinity was close to 21 (surface water). This brackish milieu leads to a low diversity of foraminifera (Hermelin, 1987; Murray, 2006). According to Lutze (1965) benthic foraminifera of this region require a minimum salinity of 11-12 to survive. The lowest salinity in our experiment was set slightly above this limit, at 15. Interestingly, the amount of incorporated $\mathrm{N}$ was higher after $7 \mathrm{~d}$ at a salinity of 15 than at a salinity of 25 , and both $\mathrm{pN}$ and $\mathrm{pC}$ were highest at a salinity of 20 (considering mean values of the uptake). Low salinities or strong salinity fluctuations can lead to smaller test sizes or test abnormalities of foraminifera (Brodniewicz, 1965; Polovodova and Schönfeld, 2008). Only foraminifera without test abnormalities were taken for experiments. After the feeding experiments, no visual influence of salinity on test abnormalities or new chambers were recorded, but the time intervals in this study were likely too short for such observations. The influence of salinity on the test structure of Elphidium in the Baltic Sea has already been investigated (e.g., Binczewska et al., 2018). At our sampling point in Laboe test abnormalities occur in 12-33 individuals per $10 \mathrm{~cm}^{3}$ (Polovodova and Schönfeld, 2008). The authors suggested a connection between the high number of abnormalities in the Kiel Fjord and the salt-rich inflows from the Belt Sea. The Belt Sea represents the interface where the low-salt waters of the Baltic Sea mixes with the salty Kattegat waters (salinities of 20-26; Hurtig, 1966). At the highest salinity (25) in this study, food uptake apparently decreased over a longer period of time. Considering the recorded amount of $\mathrm{N}$ uptake (Fig. 2), only the series for a salinity of 25 showed a negative correlation, and this trend was observed not in the series for a salinity of 15 or 20 , which indicates that $E$. excavatum was very well adapted to the brackish milieu of the Kiel Fjord.

The influences of salinity changes on foraminiferal communities in the Kiel Fjord were also investigated by Nikulina et al. (2008). As discussed before, an increase of salinity probably leads to a decrease of the amount of living E. excavatum. Nowadays, the species Ammotium cassis is barely found in the inner Kiel Fjord, while a decade ago it was a subdominant part of the foraminiferal community (Nikulina et al., 2008). This shows how important changes of the salinity are for changes in the foraminiferal communities. According to Lutze (1965), A. cassis is well adapted to a strong halocline between the surface and deep waters. Several factors contribute to the formation of a halocline (Steele et al., 1995; Rudels et al., 1996). Generally, eutrophication and increased storm frequency are important issues in the Baltic Sea (Christiansen et al., 1996; Seidenkranz, 1993). These factors can lead to a better mixing of the water masses and thus reduce the halocline and influence the faunal composition. However, the inner Kiel Fjord is less saline than the open Kiel Bight, and the fauna is dependent on the salinity of the water (Nikulina et al., 2008; Lutze 1965). 
In summary, we found significant differences in food uptake at different salinities. Elphidium excavatum seems to cope better with lower salinities, which correlates very well with the brackish milieu in the Kiel Fjord. An increase of the salinity from 20 to 25 caused more stress for the species than a reduction from 20 to 15 (see reduced uptake of $\mathrm{C}$ and $\mathrm{N}$ after $7 \mathrm{~d}$ at higher salinities in Fig. 2). This once again demonstrates the good adaptation of E. excavatum to habitats of lower salinity. Foraminifera can convert up to $15 \%$ of the total annual flux of particulate organic matter in the Kiel Fjord (Altenbach, 1985). In addition, this region is strongly affected by eutrophication, making the Kiel Fjord an interesting locality for research in the future, where interactions of changing environmental parameters with foraminiferal communities can be studied.

Data availability. Data are available in the Supplement.

Supplement. The supplement related to this article is available online at: https://doi.org/10.5194/bg-18-1395-2021-supplement.

Author contributions. The study was planned by ML, BB and PH. ML and BB sampled the material on board and performed the lab work. NK organized the trip with the research vessel and critically revised the paper. WW performed the isotopical analysis and critically revised the paper.

Competing interests. The authors declare that they have no conflict of interest.

Review statement. This paper was edited by Koji Suzuki and reviewed by three anonymous referees.

\section{References}

Abelman, A.: Paleoekologische und ökostratigraphische untersuchungen von Diatomeen-assoziationen an holozänen Sedimenten der zentralen Ostsee, Berichte-Reports, Geoloogisch.Paläontologisches Institut der Universität Kiel, 9, 1-200, 1985.

Altenbach, A.: Die Biomasse der benthischen Foraminiferen. Auswertung von "Meteor" - Expedition im östlichen Nordatlantik, Dissertation an der Christian-Albrechts-Universität zu Kiel, 133 pp., 1985.

Bak, M., Witkowski, A., and Lange-Bertalot, H.: Diatom flora diversity in the strongly eutrophicated and $\beta$-mesosaprobic waters of the Szczecin Lagoon, NW Poland, southern Baltic Sea, Ognjanova-Rumenova, N. and Manylov, K., Advances in Phycological studies, Festschrift in Honour of Prof. Dobrina Teminskova-Topalova, 293-317, 2006.

Bernhard, J. and Alve, E.: Survival, ATP pool, and ultrastructural characterization of benthic foraminifera from Drammensfjord
(Norway): response to anoxia, Mar. Micropaleontol., 28, 5-17, 1996.

Bernhard, J. and Bowser, S.: Benthic foraminifera of dysoxic sediments: chloroplast sequestration and functional morphology, Earth-Sci. Rev., 46, 149-165, 1999.

Binczewska, A., Moros, M., Polovodova-Asteman, I., Sławinska, J., and Bak, M.: Changes in the inflow of saline water into the Bornholm Basin (SW Baltic Sea) during the past 7100 years - evidence from benthic foraminifera record, Boreas, 47, 297-310, 2018.

Boltovskoy, E. and Wright, R.: Recent Foraminifera, W. Junk, The Hague, 515 pp., 1976.

Brodniewicz, I.: Recent and some Holocene foraminifera of the southern Baltic Sea, Acta Palaeontol. Pol., 10, 131-157, 1965.

Cedhagen, T.: Retention of chloroplasts and bathymetric distribution in the Sublittoral Foraminiferan Nonionellina labradorica, Ophelia, 33, 17-30, 1991.

Cevasco, M., E., Lechliter, S., M., Mosier, A., E., and Perez, J.: Initial Observations of Kleptoplastidy in the Foraminifera of Coastal South Carolina, Southeast. Nat., 14, 361-372, 2015.

Christiansen, C., Kunzendorf, H., Laima, M., Lund-Hansen, L., and Pedersem, A.: Recent changes in environmental conditions in the southwestern Kattegat, Scandinavia, Norg. Geol. Unders. B., 430, 137-144, 1996.

Correia, M. and Lee, J.: Chloroplast retention by Elphidium excavatum (Terquem). Is it a selective process?, Symbiosis, 29, 343355, 2000.

Correia, M. and Lee, J.: Fine Structure of the Plastids Retained by the Foraminifer Elphidium excavatum (Terquem), Symbiosis, 32, 15-26, 2001.

Correia, M. and Lee, J.: Fine Structure of the Plastids Retained by the Foraminifer Elphidium excavatum (Terquem), Symbiosis, 32, 15-26, 2002.

Darling, K., Schweizer, M., Knudsen, K., Evans, K., Bird, C., Roberts, A., Filipsson, H., Kim, J., Gudmundsson, G., Wade, C., Sayer, M., and Austin, W.: The genetic diversity, phylogeography and morphology of Elphidiidae (Foraminifera) in the Northeast Atlantic, Mar. Micropaleontol., 129, 1-23, 2016.

Dissard, D., Nehrke, G., Reichart, G., and Bijma, J.: The impact of salinity on the $\mathrm{Mg} / \mathrm{Ca}$ and $\mathrm{Sr} / \mathrm{Ca}$ ratio in the benthic Foraminifera Ammonia tepida: Results from culture experiments, Geochim. Cosmochim. Ac., 74, 928-940, 2009.

Enge, A., Nomaki, H., Ogawa, N., Witte, U., Moeseneder, M., Lavik, G., Ohkouchi, N., Kitazato, H., Kucera, M., and Heinz, P.: Response of the benthic foraminiferal community to a simulated short-term phytodetritus pulse in the abyssal North Pacific, Mar. Ecol. Prog. Ser., 438, 129-142, 2011.

Falkowski, P. and Raven, J.: Aquatic photosynthesis, Princeton University Press, Princeton, New Jersey, 2007.

Fennel, W.: Wasserhaushalt und Strömungen, in: Rheinheimer, Meereskunde der Ostsee, Springer Verlag, Berlin, 56-67, 1996.

Frenzel, P., Tech, T., and Bartholdy, J.: Checklist and annotated bibliography of recent Foraminifera from the German Baltic Sea coast, Stud. Geol. Polon., 124, 67-86, 2005.

Frontalini. F., Curzi, D., Giordano, F., Bernhard, J., Falcieri, E., and Coccioni, R.: Effects of Lead Pollution on Ammonia Parkinsoniana (Foraminifera): Ultrastructural and $\mathrm{Mi}$ croanalytical Approaches, Eur. J. Histochem., 59, 2460, https://doi.org/10.4081/ejh.2015.2460, 2015. 
Frontalini, F., Curzi, D., Cesarini, E, Canonico, B., Giordano, F., Matteis, F., Bernhar, J., Pieretti, N., Eskelsen, G., Jubb, J., Zhao, A., Pierce, L., Gobbi, E., Papa, P., and Coccioni, R.: Mercury-Pollution Induction of Intracellular Lipid Accumulation and Lysosomal Compartment Amplification in the Benthic Foraminifer Ammonia parkinsoniana, Plos one, 11, e0162401, https://doi.org/10.1371/journal.pone.0162401, 2016.

Goldstein, S., Bernhard, J., and Richardson, E.: Chloroplast Sequestration in the Foraminifer Haynesina germanica: Application of High Pressure Freezing and Freeze Substitution, Microsc. Microanal., 10, 1458-1459, 2004.

Grobe, H. and Fütterer, D.: Zur Fragmentierung benthischer Foraminifera in der Kieler Bucht (Westliche Ostsee), Meyniana, 33, 85-96, 1981.

Grzymski, J., Schönfield, J., Falkowski, P., and Bernhard, J.: The function of plastids in the deep-sea benthic foraminifer, Nonionella stella, Limnol. Oceanogr., 47, 1569-1580, 2002.

Guillard, R.: Culture of phytoplankton for feeding marina invertebrates in: Culture of marine invertebrates animals, Springer, Woods Hole, Massachusetts, 29-60, 1975.

Guillard, R. and Ryther, J.: Studies of marina planktonic diatoms: I Cyclotella nana Hustedt, and Detonula confervacea (CLEVE) Gran, Can. J. Microbiol., 8, 229-239, 1962.

Hannah, F., Rogerson R., and Laybourn-Parry, J.: Respiration rates and biovolumes of common benthic Foraminifera (Protozoa), J. Mar. Biol. Assoc. UK, 72, 301-312, 1994.

Heinz P., Marten R., Linshy V., Haap T., Gesling E., and Köhler H.: $70 \mathrm{kD}$ stress protein (Hsp70) analysis in living shallowwater benthic foraminifera, Mar. Biol. Res., 8, 677-681, 2012.

Hermelin, J.: Distribution of Holocene benthic foraminifera in the Baltic Sea, J. Foramin. Res., 17, 63-72, 1987.

Hurtig, T.: Fragen zur Genese der naturräumlichen Grosseinheiten des Ostseeraumes (Problems in the Origin of the Major Natural Units of the Baltic Sea Area), Erdkunde, 20, 287-298, 1966.

Jauffrais, T., Jesus, B., Metzger, E., Mouget, J.-L., Jorissen, F., and Geslin, E.: Effect of light on photosynthetic efficiency of sequestered chloroplasts in intertidal benthic foraminifera (Haynesina germanica and Ammonia tepida), Biogeosciences, 13, 2715-2726, https://doi.org/10.5194/bg-13-2715-2016, 2016.

Jauffrais, T., LeKieffre, C., Koho, K., Tsuchiya, M., Schweizer, M., Bernhard, J., Meibom, A., and Geslin, E.: Ultrastructure and distribution of kleptoplasts in benthic foraminifera from shallowwater (photic) habitats, Mar. Micropaleontol., 138, 46-62, 2018.

Jauffrais, T., LeKieffre, C., Schweizer, M., Geslin, E., Metzger, E., Bernhard, J., Jesus, B., Filipsson, H., Maire, O., and Meibom, A.: Kleptoplastidic benthic foraminifera from aphotic habitats: insights into assimilation of inorganic $\mathrm{C}, \mathrm{N}$ and $\mathrm{S}$ studied with subcellular resolution, Environ. Microbiol., 21, 125-141, 2019a.

Jauffrais, T., LeKieffre, C., Schweizer, M., Jesus, B., Metzger, E., and Geslin, E.: Response of a kleptoplastidic foraminifer to heterotrophic starvation: photosynthesis and lipid droplet biogenesis, FEMS Microbiol. Ecol., 95, fiz046, https://doi.org/10.1093/femsec/fiz046, 2019b.

Jensen, J. B., Bennike, O., Witkowski, A., Lemke, W., and Kuijpers, A.: The Baltic Ice Lake in the southwestern Baltic: sequence-, chrono- and biostratigraphy, Boreals, 26, 217-236, 1997.

Koho, K., LeKieffre, C., Nomaki, H., Salonen, I., Geslin, E., Mabilleau, G., Sogaard, J., and Reichert, G.: Changes in ultrastructural features of the foraminifera Ammonia spp. in response to anoxic conditions: Field and laboratory observations, Mar. Micropaleontol, 138, 72-82, 2018.

Krause, G. and Weis, E.: Chlorophyll fluorescence and photosynthesis: The Basics, Annu. Rev. Plant Physio., 42, 313-349, 1991.

Lechliter, S.: Preliminary study of kleptoplasty in foraminifera of South Carolina, Bridges, 8, 43-54, 2014.

Le Cadre, V. and Debenay, J.: Morphological and cytological responses of Ammonia (foraminifera) to copper contamination: Implication for the use of foraminifera as bioindicators of pollution, Environ. Pollut., 143, 304-317, 2006.

Lee, J. and Lee, R.: Chloroplast retention in elphids (Foraminifera), Endocyto., 4, 215-220, 1989.

Lee, J. and Müller, W.: Trophic dynamics and niches of salt marsh foraminifera, Am. Zool., 13, 215-223, 1973.

Lee, J., Price S., Tentchoff, M., and McLaughin, J.: Growth and Physiology of Foraminifera in the Laboratory: Part 1: Collection and Maintenance, Micropaleontology, 7, 461-466, 1961.

Lee, J., McEnery, M., Pierce, S., Freudenthal, H., and Muller, W.: Tracer Experiments in Feeding Littoral Foraminifera, J. Eukaryot. Microbiol., 13, 659-670, 1966.

Lee, J., Lanners, E., and Kuile, B.: The retention of chloroplasts by the foraminifer Elphidium crispum, Symbiosis, 5, 45-59, 1988.

LeKieffre, C., Spangenberg, J., Mabilleau, G., Escrig, S., Meibom, A., and Geslin, E.: Surviving anoxia in marine sediment: The metabolic response of ubiquitous benthic foraminifera (Ammonia tepida), Plos one, 12, e0177604, https://doi.org/10.1371/journal.pone.0177604, 2017.

LeKieffre, C., Spero, H. J., Russell, A. D., Fehrenbacher, J. S., Geslin, E., and Meibom, A.: Assimilation, translocation, and utilization of carbon between photosynthetic symbiotic dinoflagellates and their planktic foraminifera host, Mar. Biol., 165, 104, https://doi.org/10.1007/s00227-018-3362-7, 2018.

Lintner, M., Biedrawa, B., Wukovits, J., Wanek, W., and Heinz, P.: Salinity-dependent algae uptake and subsequent carbon and nitrogen metabolisms of two intertidal foraminifera (Ammonia tepida and Haynesina germanica), Biogeosciences, 17, 3723-3732, https://doi.org/10.5194/bg-17-3723-2020, 2020.

Lopez, E.: Algal chloroplasts in the protoplasm of three species of benthic foraminifera: taxonomic affinity, viability and persistence, Mar. Biol., 53, 201-211, 1979.

Lutze, G.: Zur Foraminiferen: Fauna der Ostsee, Meyniana, 15, 75$142,1965$.

Mackinney, G.: Absorption of light by chlorophyll solutions, J. Biol. Chem., 140, 315-322, 1941.

Middelburg, J., Barranguet, C., Boschker, H., Herman, P., Moens, T., and Heip, C: The fate of intertidal microphytobenthos carbon: An in situ ${ }^{13} \mathrm{C}$-labeling study, Limnol. Oceanogr., 45, 1224-1234, 2000.

Miller, A., Scott, D., and Medioli, F.: Elphidium excavatum (Terquem): ecophenotypic versus subspecific variation, J. Foramin. Res., 12, 116-144, 1982.

Murray, J.: Ecological experiments on Foraminifera, J. Mar. Biol. Assoc. UK, 43, 621-642, 1963.

Murray, J.: Ecology and paleoecology of benthic foraminifera, Longman, Harlow, 1991.

Murray, J.: Ecology and Applications of Benthic Foraminifera, Cambridge, New York, Melbourne, Madrid, Cape Town, Singapore, Sao Paulo, 426, 2006. 
Nikulina, A., Polovodova, I., and Schönfeld, J.: Environmental response of living benthic foraminifera in Kiel Fjord, SW Baltic Sea, HAL archieves-ouvertes, Hal Id: hal-00298257, 2007.

Nikulina, A., Polovodova, I., and Schönfeld, J.: Foraminiferal response to environmental changes in Kiel Fjord, SW Baltic Sea, eEarth, 3, 37-49, https://doi.org/10.5194/ee-3-37-2008, 2008.

Nomaki, H., Chikaraishi, Y., Tsuchiya, M., Ohkouchi, N., Uematsu, K., Tame, A., and Kitazato, H.: Nitrate uptake by foraminifera and use in conjunction with endobionts under anoxic conditions, Limnol. Oceanogr., 59, 1879-1888, 2014.

Pawlowski, J., Holzmann, M., Bemey, C., Fahmi, J., Gooday, A., Cedhagen, T., Habura, A., and Bowser, S.: The Evolution of early Foraminifera, P. Natl. Acad. Sci. USA, 100, 11494-11498, 2003.

Pillet, L., Vargas, C., and Pawlowski, J.: Molecular identification of sequestered diatom chloroplasts and kleptoplastidy in foraminifera, Protist, 162, 394-404, 2011.

Polovodova, I. and Schönfeld, J.: Foraminiferal test abnormalities in the Western Baltic Sea, J. Foramin. Res., 38, 318-336, 2008.

Rhode, S., Hiebenthal, C., Wahl, M., Karez, R., and Bischof, K.: Decreased depth distribution of Fucus vesiculosus (Phaeophyceae) in the Western Baltic: effects of light deficiency and epibionts on growth and photosynthesis, Eur. J. Phycol., 43, 143150, 2008.

Robertsson, A. M.: The diatom flora of the Yoldia sediments in the Närke province, south central Sweden. Contributions to the Knowledge of Microalgae Particularly Diatoms, Cramer, Berlin Stuttgart, 255-262, 1990.

Ross B. and Hallock P.: Dormancy in the foraminifera: A review, J. Foramin. Res., 46, 358-368, 2016.

Rudels, B., Anderson, L., and Jones, E.: Formation and evolution of the surface mixed layer and halocline of the Arctic Ocean, J. Geophys. Res., 101, 8807-8821, 1996.

Salonen, I., Chronopoulou, P., Bird, C., Reichert, G., and Koho, K.: Enrichment of intracellular sulphur cycle associated bacteria in intertidal benthic foraminifera revealed by $16 \mathrm{~S}$ and aprA gene analysis, Sci. Rep.-UK, 9, 11692, https://doi.org/10.1038/s41598-019-48166-5, 2019.

Scott, D., Mediolo, F., and Braund, R.: Foraminifera from the Cambrian of Nova Scotia: The oldest multichambered foraminifera, Micropaleontology, 49, 109-126, 2003.

Seidenkrantz, M.: Subrecent changes in the foraminiferal distribution in the Kattegat and the Skagerrak, Scandinavia: anthropogenic influence and natural causes, Boreas, 22, 383-395, 1993.
Steele, M., Morison, J., and Curtin, T.: Halocline water formation in the Barents Sea, J. Geophys. Res., 100, 881-894, 1995.

Schönfeld, J. and Numberger, L.: Seasonal dynamics and decadal changes of benthic foraminiferal assemblages in the western Baltic Sea (NW Europe), J. Micropalaeontol., 26, 47-60, 2007.

Schwarzer, K. and Themann, S.: Sediment distribution and geological buildup of Kiel Fjord (Western Baltic Sea), Meyniana, 55, 91-115, 2003.

Schweizer, M., Polovodova, I., Nikulina, A., and Schönfeld, J.: Molecular identification of Ammonia and Elphidium species (Foraminifera, Rotaliida) from the Kiel Fjord (SW Baltic Sea) with rDNA sequences, Helgoland Mar. Res., 65, 1-10, 2011.

Terquem, O.: Essai sur le classement des animaux qui vivent sur la plage et dans les environs de Dunkerque, pt. 1, Memoires de la Societe Dunkerquoise pour l'Encouragement des Sciences, des Lettres et des Arts, 19, 405-457, 1876.

Tsuchiya, M., Toyofuko, T., Uematsu, K., Bruchert, V., Collen, J., Yamamoto, H., and Kitazato, H.: Cytologic and genetic characteristics of endobiotic bacteria and kleptoplasts of Virgulinella fragilis (Foraminifera), J. Eukaryot. Microbiol., 62, 454-469, 2015.

Tsuchiya, M., Miyawaki, S., Oguri, K., Toyofuku, T., Tame, A., Uematsu, K., Takeda, K., Sakai, Y., Miyake, H., and Marayuma, T.: Acquisition, Maintenance, and Ecological Roles of Kleptoplasts in Planoglabratella opercularis (Foraminifera, Rhizaria), Front. Mar. Sci. 7, 585, https://doi.org/10.3389/fmars.2020.00585, 2020.

Voipio, A.: The Baltic Sea (Book), Elsevier Oceanography Series 30, Institute of Marine Research, Helsinki, Finland, 1981.

Witkowski, A.: Recent and fossil diatom flora of the Gulf of Gdansk, Southern Baltic Sea, Bibliotheca Diatomologica, Band 28, ISBN 978-3-443-57019-4, 1994.

Weiss, L.: Foraminifera and Origin of the Gardiners Clay (Pleistocene), Eastern Long Island, New York, Geol. Survey Professional Paper, 254-G, 1954.

Williamson, W.: On the recent foraminifera of Great Britain (Book), Ray Society, London, 107, 1858.

Wukovits, J., Enge, A. J., Wanek, W., Watzka, M., and Heinz, P.: Increased temperature causes different carbon and nitrogen processing patterns in two common intertidal foraminifera ( $\mathrm{Am}$ monia tepida and Haynesina germanica), Biogeosciences, 14, 2815-2829, https://doi.org/10.5194/bg-14-2815-2017, 2017. 